Texas A\&M University-San Antonio

Digital Commons @ Texas A\&M University-San Antonio

Criminology and Criminal Justice Faculty

Publications

2018

Modeling Job Stress Among Police Officers: Interplay of Work

Environment, Counseling Support, and Family Discussion with Co-

Workers

Lily Chi-Fang Tsai

Claire Nolasco

Michael S. Vaughn

Follow this and additional works at: https://digitalcommons.tamusa.edu/crim_faculty

Part of the Criminology and Criminal Justice Commons 


\title{
Modeling Job Stress Among Police Officers: Interplay of Work Environment, Counseling Support, and Family Discussion with Co-Workers
}

\begin{abstract}
Existing literature indicates that various factors affect police stress. This article uses data from the "Work and Family Services for Law Enforcement Personnel in the United States, 1995" downloaded from the Inter-University Consortium for Political and Social Research ("ICPSR”) website. Respondents include 594 sworn police officers from 21 agencies in New York City. Using structural equation modeling, results indicate that sex, race, education, and tenure do not have a direct influence on total job stress, but have a direct impact on family discussion with coworkers, counseling support, and negative working environment. Rank has a direct impact on total job stress and both negative working environment and family discussion with co-workers. In addition, both negative working environment and counseling support directly impact police total job stress.
\end{abstract}

Keywords: police stress; work environment; counseling support; job stress 


\section{Modeling Job Stress of Police Officers: Interplay of Work Environment, Counseling Support, and Family Discussion with Co-Workers}

\section{Introduction}

Existing literature examines the concept of job stress in police agencies (Alexander, Innes, Irving, Sinclair, \& Walker, 1991; Ayres \& Flanagan, 1990; Band \& Manuelle, 1987; Biggam, Power, MacDonald, Carcary, \& Moodie, 1997; Crowe \& Stradling, 1993; Greller, Parsons, \& Mitchell, 1992; Gudjonsson \& Adam, 1985; Hart, Wearing, \& Headley, 1994, 1995; Silbert, 1982) and the methods that enable police organizations and police officers to cope with stress (Brown \& Campbell, 1994; Finn, 1997, 1999; Graves, 1996; Kirschman, 1998; Sewell, 1999; Stinchcomb, 1995, 2004; Territo \& Sewell, 1999). Others studies focus on how police stress affects job performance and productivity (Hawkins, 2001; Jespersen, 1988; Jackson \& Maslach, 1982; Maslach \& Jackson, 1981; Stotland, Pendleton, \& Swartz, 1989).

Few studies, however, use higher level data analysis to measure the complex relationships between work environment (availability of human resources, such as counseling support and peer support) and job stress. Existing studies are either descriptive or provide less sophisticated means of analyzing the interrelationship between these variables (Korre, Farioli, Varvarigou, Sato, \& Kales, 2014). The Law Enforcement Organization (“LEO”) Survey of the National Police Research Platform, for instance, surveyed a random sample of 13,146 sworn officers in 89 police and sheriff's offices in the Northeastern, Midwestern, Southern, and Western parts of the United States. The final report of the National Police Research Platform on Stress, Burnout, and Health found, among others, that lack of trust among co-workers was positively correlated with both burnout $(\mathrm{r}=.347, \mathrm{p}<.05)$ and physical stress $(\mathrm{r}=.265, \mathrm{p}<.05)$, and 
negatively correlated with health $(r=-.247, \mathrm{p}<.05)$ (McCarthy, Schuck, Skogan, \& Rosenbaum, 2011). Burnout and physical stress increase as the distrust among co-workers increases. The dataset however, did not specifically measure factors affecting trust among co-workers. Instead, respondents were asked to what extent they agree with the statement that they "feel a lack of trust among co-workers" (McCarthy et al., 2011, p. 4). The report recommended that future research should focus on the "perceived availability of, and incentives for using, human resources (e.g. counseling services, peer supports), workout facilities, and other stress-reducers" (McCarthy et al., 2011, p. 6).

In line with this recommendation, this article examines the influence of work support for counseling services and peer support on police stress. To measure the correlation between these variables, the article used structural equation modeling to analyze a dataset titled, "Work and Family Services for Law Enforcement Personnel in the United States, 1995, " which contains specific questions on work support for counseling and ability of co-workers to discuss family lives at work with colleagues.

Recent studies that use structural equation modeling in their analyses of police stress examine data gathered from police departments in other countries, such as Britain (Ortega, Brenner, \& Leather, 2007), Germany (Ellrich, 2016), India (Tyagi \& Dhar, 2014), South Korea (Yun, Hwang, \& Lynch, 2015), and Turkey (Kula, 2017), or use survey data from a convenience sample instead a random sample of respondents (Higgins, Ercikti, \& Vito, 2013). Higgins et al. (2013), for instance, used structural equation modeling to analyze survey data from a convenience sample of 136 police managers attending the Administrative Officers' Course or the Commanding Officer Development Course offered by the Southern Police Institute under the Department of Justice Administration at the University of Louisville. Other studies examined the 
relationship between participation in decision-making at work and job stress among a convenience sample of police officers (Slate, Johnson, \& Colbert, 2007). To date, there is no study that uses structural equation modeling to analyze survey data from a random sample of police officers in the United States to determine the interplay between job stress, counseling support at work, and family discussion with co-workers. Through considering latent and observed variables as well as measurement error terms simultaneously, this article adds to the literature by using structural equation modeling to analyze the influence of demographic variables, counseling support at work, and work environment on job stress among a relatively large sample of 594 sworn police officers from 21 agencies in New York City.

\section{Literature Review}

Since the Hawthorne experiment in 1924, organizational behavioral studies have primarily focused on employee productivity and job performance (Franke \& Kaul, 1978). The 1924 experiment involved a team of researchers who conducted experiments with the lighting conditions of a group of employees at the Hawthorne plant of the Western Electric Company near Chicago. Results showed that the lighting conditions did not affect worker productivity, contrary to the expectations of the research team (Ott, Parkes, \& Simpson, 2008). The experiment led to other theories of worker motivation, including Herzberg's motivation-hygiene theory (Herzberg, 2005). Herzberg differentiated between factors that lead to job dissatisfaction ("hygiene factors"), such as company policy and administration, supervision, relationship with supervisor, work conditions, salary, relationship with peers and subordinates, personal life, status, and security to factors that lead to job satisfaction ("motivators"), such as achievement, recognition, work and responsibilities, advancement, and growth (Bolman \& Deal, 2003). 
Management policies that focus on hygiene factors tend to lessen or eliminate job dissatisfaction, while policies that focus on motivators increase job satisfaction among employees.

Current studies similarly analyze job productivity and motivation in the public sector, including law enforcement agencies. Zhao, Thurman, and He (1999), for example, examined the effects of demographic variables (ethnicity, gender, educational attainment, years of service, and rank) to job dimensions (skill variety, task identity, task significance, autonomy, and feedback) on police job satisfaction (satisfaction with work, supervisor, and co-workers). They found that work environment or job dimensions accounted for over $40 \%$ of the variance in job satisfaction. On the other hand, job autonomy explained only $17 \%$ of the variance in satisfaction with coworkers. Their study showed that job dimensions explained more variation in job satisfaction than the demographic attributes of police officers.

\section{Nature of Job Stress and Burnout}

Police officers who are exposed to the daily demands of the job are more susceptible to stress and burnout (Chu, 2015; Veniga \& Spradley, 1981), resulting into apathy and lack of concern for clients (Maslach, 1976) and other physiological disorders and addictions (Violanti, 1996). Due to the possible effects of job stress on psychological and physiological health of police officers, several scholars have examined the causes of stress and its concomitant effects on productivity (Pagon, Spector, Cooper, \& Lobnikar, 2011).

Hawkins (2001) examined the effects of burnout and organizational stress among 452 sworn police officers in four police departments. He found that female officers experienced lower depersonalization scores, married officers had higher emotional exhaustion compared to non-married officers, and White officers had higher emotional exhaustion and depersonalization 
scores. He also found that length of service in law enforcement was positively and significantly correlated with emotional exhaustion (Hawkins, 2001).

Police stress remains a concern among police departments due to the negative consequences associated with it, including poor health (Cooper \& Davidson, 1987; Fletcher, 1988; Kirkcaldy, Cooper, \& Ruffalo, 1995), periodic absence from work (Wright \& Saylor, 1991), and premature retirement (Kop, Euwema, \& Schaufeli, 1999; Malloy \& Mays, 1984; Stevenson, 1988).

\section{Factors Affecting Stress}

Studies show that workplace stress arises due to lack of control over the circumstances of employment (Morash, Haarr, \& Kwak, 2006). Lack of job autonomy and control significantly increases job stress (Pagon et al., 2011; Stinchcomb, 2004). Stress is classified as either periodic or intermittent. Stinchcomb (2004), for example, distinguishes between episodic stress (intermittent) or traumatic incidents that any police officer may encounter sporadically (e.g., high speed chases, gun-fighting, or deployment to major accident scenes) and chronic organizational stress (periodic) that a police officer encounters on a daily and sustained basis (e.g., organizational management practices) (Stinchcomb, 2004; Walker, 1997). To prevent chronic organizational stress, Stinchcomb (2004) recommends that management employ a more participatory style of leadership and implement strategies such as team-building, empowering employees, improving communication among leadership and employees, and changing stressinducing organizational policies and practices.

\section{Demographic Variables}

Stress may be classified according to whether it is caused by static or dynamic attributes. He, Zhao, and Ren (2005), for instance, explain that studies on police stress focus on static 
factors, such as race and gender (Belknap \& Shelley, 1992; Buzawa, 1984; Hunt \& McCadden, 1985; Love \& Singer, 1988) or on dynamic factors, such as work environment and coping mechanisms. He et al. (2005) examined the effects on police stress of static factors, such as race and gender and dynamic factors, including work environment, work-family conflict, and coping mechanisms. Their study showed that female officers exhibited higher levels of stress than males; White male officers were more stressed than African-American male officers, and African-American female officers were not more stressed than White female officers. They also found that "dynamic factors," such as work environment and coping mechanisms explained more variance in police stress than "static factors," such as "race and gender" (He et al., 2005, p. 535). Hawkins (2001, p. 358), however, found that "White officers seemed to be more prone to emotional exhaustion and to have higher depersonalization scores." Conversely, Kanter (1977) reported that membership in a racial minority group and sex of respondents significantly predicts higher levels of stress. Krimmel and Gormley (2003), for example, found that women in departments with less than $15 \%$ females had high levels of job-related depression and low selfesteem.

Other scholars examine the relationship between job stress and various demographic variables such as educational background (Carter \& Sapp, 1990; Dantzker, 1992; Lefkowitz, 1974; Sherman, 1980), ethnicity and sex (Belknap \& Shelley, 1992; Buzawa, 1984; Hunt \& McCadden, 1985; Love \& Singer, 1988; Morash et al., 2006), years of service and police officer rank (Burke, 1989; Dantzker, 1992). Some studies show that female officers have statistically higher levels of stress than male officers (Backteman-Erlanson, Padyab, \& Brulin, 2013; Dowler \& Arai, 2008; Kurtz, 2012). Morash and Kwak (2006) found that workplace problems significantly predicted $24 \%$ of the variance in stress among female officers while workplace 
problems explained 36\% of the variance in stress among male officers (Morash \& Kwak, 2006). Their study also showed that, "regardless of gender, the strongest predictor of stress was bias of coworkers, and a weaker predictor was language harassment" (Morash \& Kwak, 2006, p. 541). Stotland et al. (1989) found that higher ranking officers were less stressed than lower ranking officers. Also, officers with six to 10 years of service were more stressed than those with one to five years of service (Violanti \& Aron, 1995).

\section{Work Environment}

Organizational structure. Other scholars identify the following sources of organizational stress: authoritarian structures (Standfest, 1996; Violanti \& Aron, 1995), lack of participation in decisions affecting daily work tasks (Brown \& Campbell, 1994; Kirkcaldy et al., 1995), lack of administrative support (Ayres \& Flanagan, 1990; Kirschman, 1998; Spielberger, Westberry, Grier, \& Greenfield, 1981), unfair discipline (Violanti \& Aron, 1995), work conditions, conflict with supervisors, and relationships with non-police (Crank \& Caldero, 1991; Sigler \& Wilson, 1988; Sigler, Wilson, \& Allen, 1991; Storch \& Panzarella, 1996). Chronic organizational stress leads to diminished job satisfaction (Leitner, Posner, \& Lester, 1983;

Lester, Benkovich, Dietrich, \& Solis, 1981; Stinchcomb, 2004). Thus, Morash et al. (2006, p. 36) argue that in order to eliminate job stress caused by organizational structure:

[f]ull implementation of community policing might be a way to allow officers greater discretion and control of their work, and many departments have been able to implement this approach to policing either for some or, in a few cases, all types of officers.

Contrary to the argument of Morash et al. (2006) that greater control in decision-making will diminish job stress, Lord (1996, p. 514) found that in a police department that implemented 
an organizational change from traditional to community-based policing, "the more the sergeants feel they are participating in decision-making, the more strain they appear to have in response.” Their findings contradict existing literature that the more involvement given to police officers, the more control and the less stress they will experience.

Other aspects of the work environment that contribute to stress are the organizational hierarchy, closed society of policing (Morash \& Kwak, 2006), and police culture (Brown, Fielding, \& Grover, 1999; Dick, 2000; Reiser \& Geiger, 1984). Police departments that are more "militaristic," "bureaucratic," and "discipline-oriented" result in "stressors beyond what can be explained by workplace problems" (Morash \& Kwak, 2006, p. 544). Dangers associated with the job of law enforcement, such as job shifts and high crime areas, also result in stress (Oliver \& Meier, 2004). Workday length, shift arrangements, and personnel assignment also contribute to employee fatigue (Vila, Morrison, \& Kenney, 2002). Studies show that a work period lasting from 17 to 19 continuous hours can impair performance as much as having a $0.05 \%$ Blood Alcohol Concentration, and a work period of 24 continuous hours may produce impairment equivalent to a $0.10 \%$ Blood Alcohol Concentration (Dawson \& Reid, 1997; Williamson \& Feyer, 2000).

Counseling support and social support networks. Various counseling support and social support networks may reduce stress (Hart et al., 1995; McCarty \& Lawrence, 2016; Stinchcomb, 2004; Sewell, 1999). Management-led interventions that encourage team-building activities, problem-solving, and resolving conflicts (Finn, 1997), as well as training managerial staff to develop more effective management techniques (Finn, 1999) can alleviate job stress. The existence of social support networks, such as family, work supervisors, friends, and colleagues also help ameliorate stress (LaRocco, House, \& French, 1980). Lack of social support can 
exacerbate the effects of job stress on physiological and psychological health (Cullen, Lemming, Link, \& Wozniak, 1985). Ortega et al. (2007, p. 41) examined the relationship between a police officer's wellbeing and various coping mechanisms, including "a police officer's efforts and determination to tackle the problem and solve it by asking support from those in a position to help and socializing." They found that discussing the problem was positively associated only with organizational commitment $(\beta=0.46)$. They did not find any significant direct association between coping strategies and wellbeing factors (Ortega et al., 2007).

Expressing emotions associated with the job also appeared to reduce stress. Ireland, Malouff, and Byrne (2006, p. 303) found that among a sample of 67 police officers assigned to a writing intervention and a non-writing control group, the writing group experienced "significantly lower levels of stress and anxiety post-intervention." Thus, writing or expressing emotions can help reduce stress among police officers (Ireland et al., 2006). Use of various support services similarly reduces stress (Beehr, King, \& King, 1990; Cohen \& Wills, 1985).

\section{Methodology}

This article examines the association between various demographic variables (such as sex, age, race, level of education, rank, and length of employment), work environment (such as dangers associated with job, closed society of policing, relationship with superiors and top management, relationship with co-workers, organizational hierarchy, and other work-related forms of counseling and support), counseling support, family discussion with co-workers, and total job stress in law enforcement agencies. The null hypotheses are as follows: (1) there is no relationship between demographic variables and total job stress; and (2) there is no relationship between work environment and total job stress. 


\section{Data}

This article uses dataset 2 of Delprino, O'Quin, and Kennedy's (2000) study of the "Work and Family Services for Law Enforcement Personnel in the United States, 1995." The data were downloaded from the website of the Inter-University Consortium for Political and Social Research (ICPSR \#2696) funded by the National Institute of Justice. The purpose of the original project was to examine the existence and prevalence of work and family training intervention programs offered nationally by law enforcement agencies. The data were collected in 1995. The sampling frame for the project included a total of 4,400 sworn police officers in three geographic locations: the Northeast (New York City and surrounding areas), the Midwest (Minneapolis and surrounding areas), and the Southwest (Dallas and surrounding areas). Within each metropolitan agency, department personnel randomly selected officers to participate in the project. Prior to the distribution of the surveys, a $70 \%$ response rate was expected. Therefore, 560 surveys were distributed to each of the six sample groups. Approximately 4,400 surveys were sent to police officers. Responses were received from 1,632 officers, representing 51 agencies.

After data screening from 664 cases, the present article included 594 completed cases from New York City in the analyses. The researchers decided to focus their analysis on New York City and its surrounding areas because of the magnitude of police personnel and officers currently employed by the city, the greater number of constituency serviced by New York City police officers, ${ }^{1}$ and the considerable amount of workload and stress that these officers may be exposed to. The Federal Bureau of Investigation reports that in 2011, New York City employed

\footnotetext{
${ }^{1}$ New York City reported a population of $8,211,875$ in 2011 compared to Dallas which had a population size of $1,223,021$ and Minneapolis which had a population size of 385,531 in the same year (Uniform Crime Reports, 2011).
} 
49,401 law enforcement personnel of which 34,542 were commissioned officers (Uniform Crime Reports, 2011). In contrast, there were 4,052 full time law enforcement employees in Dallas, out of which 3,511 were commissioned officers (Uniform Crime Reports, 2011). Minneapolis, on the other hand, reported that it had 983 full time law enforcement employees, of which 852 were commissioned officers (Uniform Crime Reports, 2011). Police personnel in New York City alone account for $90 \%$ of the total law enforcement employees in the combined cities of New York, Dallas, and Minneapolis. On the other hand, police officers in New York City account for $88.78 \%$ of the total commissioned officers in the combined cities of New York, Dallas, and Minneapolis. The sheer size of the New York City police force warranted particular focus and attention in an effort to understand the predictors of police stress in New York City's law enforcement agencies.

\section{Dependent Variable}

This article examines the influence of demographic variables, negative work environment, counseling support, and family discussion with co-workers on total job stress among police officers. Total job stress among police officers was measured as a latent construct consisting of three questions identifying their stress levels on the following: (1) overall stress; (2) job stress; and, (3) burnout. Respondents were asked to rate the survey questions on a Likert scale from 1 (not at all or excellent) to 5 (a lot or poor). The Cronbach's alpha for this index was 0.825, indicating a high level of congruence among the three items and providing confidence in the appropriate measurement of the latent construct of police officers' total job stress. Confirmatory factor analysis scores are listed in Appendix A.

\section{Independent Variables}

\section{Demographic Model}


Six variables are included in the demographic model: sex, age, race, highest level of education, rank, and years in law enforcement. For sex, females were recoded as 0 and males as 1. Age and years in law enforcement were measured as continuous variables, ranging from 22 to 62 and from 0 to 30, respectively. Race was recoded as minority $(=0)$ and white $(=1)$. For highest level of education, respondents with less than bachelor's degree were coded as " 0 " and respondents with bachelor's degree and higher were coded as "1." Similarly, rank of job title was coded as officer $(=0)$ and supervisor $(=1)$.

\section{Work Environment}

Three variables measuring how work environment impacts job stress among police officers were included: negative working environment, counseling support, and family discussion with co-workers. The three variables are latent constructs consisting of several observed variables.

Negative working environment. The latent construct of negative working environment was created by including four survey questions examining the impact of the following on police officers and their families: (1) "Danger associated with the job"; (2) "Closed society of policing"; (3) "Organizational hierarchy of the department”; and, (4) "Officer \& family are expected to behave by a higher set of standards." Responses were coded on a Likert scale from 1 (not at all) to 5 (a lot). The Cronbach's alpha for this index was 0.670 .

Counseling support. The latent construct of counseling support was created by including four survey questions that asked police officers how strongly they agree or disagree with different sources of support for counseling at the workplace: (1) "My supervisor is supportive of officers who seek counseling"; (2) “Top management supports officers seeking counseling"; (3) "My fellow officers back up officers seeking counseling"; and, (4) "My union supports officers 
who seek counseling." Responses were coded on a Likert scale from 1 (strongly disagree) to 5 (strongly agree) so that higher scores reversely represent lower levels of job stress. The Cronbach's alpha for this index was 0.898 .

Family discussion with co-workers. To measure the influence of family discussion with co-workers on total job stress, this latent construct was created by including two survey questions that asked police officers how strongly they agree or disagree with the following statements: (1) "I discuss my family experiences with co-workers"; and (2) "I discuss my family with co-workers." Responses were coded on a Likert scale from 1 (strongly disagree) to 5 (strongly agree) so that the higher scores reversely represent lower levels of job stress. The Cronbach's alpha for this index was 0.778 .

\section{Structural Equation Modeling}

Structural equation modeling (“SEM") has been applied to measure simultaneously the latent concepts and the structural relationships among exogenous and endogenous variables derived from the research hypotheses (Kula \& Sahin, 2015). Schumacker and Lomax (2004) contend that SEM provides multiple observed variables to better understand theoretical models. Including latent and observed variables as well as measurement error terms in SEM makes greater validity and reliability of observed scores from measurement instruments. SEM is becoming more acceptable by social science researchers because it allows an increase in capability to analyze sophisticated theoretical models for complex phenomena. In this article, AMOS 17.0 was used to conduct all analyses, and the maximum likelihood algorithm was used to estimate parameters.

A variety of absolute and incremental fit indices were consulted to evaluate the model. By determining the value of CMIN/DF (Schuck \& Rosenbaum, 2005), the absolute fit index 
assess if the model fit is acceptable. CMIN represents the Chi-square statistic $\left(\chi^{2}\right)$, which is used to investigate whether a model provides an acceptable fit to the observed data. As a general rule, CMIN can be two or three times larger than DF, and the hypothesized model can still fit well (Carmines \& McIver, 1981; Gibson, Zhao, Lovrich, \& Gaffney, 2002; Kline, 2005). Dukes, Portillos, and Miles (2009) contend that a model fit of 4.00 was acceptable with a large sample size since the Chi-square statistic is sensitive and inflated by a large sample size (Iwasaki, 2003; Ortega et al., 2007).

Other indices used to investigate the level of fitness between the model and the data include the goodness-of-fit index (GFI), the adjusted goodness-of-fit index (AGFI), the comparative fit index (CFI), and the root-mean-square error of approximation (RMSEA). The GFI value (ranging from 0 to 1.00) assesses the overall fit of the model by estimating a ratio of the squared sum of discrepancies to the observed variances (Jöreskog \& Sörbom, 1989). Studies show that a GFI value close to 1 indicates a good model fit (Schumacker \& Lomax, 2004). The AGFI index is adjusted for the degrees of freedom of a model relative to the number of variables. A value of 0.90 or larger for the AGFI represents a good model fit for this measure (Hoyle \& Panter, 1995). Similarly, the CFI value examines how well a hypothesized model captures all of the covariance among the variables (Dukes et al., 2009). The CFI value of a good fit of the hypothesized model should range between 0.90 and 1.00 , or exceed 0.95 for a very well-fitting model (Dukes et al., 2009; Hu, Bentler, \& Kano, 1992). Lastly, RMSEA includes the error of population approximation and degrees of freedom to measure the lack of fit of the hypothesized model to the population covariance matrix. For a close approximate fit of the model, the RMSEA value should be less than 0.05 , which represents a good fit between the hypothesized model and the observed data (Bentler, 2006; Hu \& Bentler, 1999). 


\section{The Hypothesized Model}

In the hypothesized model in Figure 1, six demographic variables (sex, age, race, education, rank, and years police officers served in law enforcement), negative working environment, counseling support, family discussion with co-workers, and total job stress were included in the analysis. Theoretically, demographic variables influence police total job stress both directly and indirectly. Personal characteristics, such as sex, age, race, education, rank, and tenure, have a direct impact on police officers' total job stress. In addition, demographic factors are also expected to separately link all the three endogenous variables-negative working environment, counseling support, and family discussion with co-workers—and therefore indirectly play important roles in causing total job stress among police officers. Meanwhile, negative working environment, counseling support, and family discussion with co-workers were all expected to directly influence police officers' total job stress. At the same time, indirect influences on total job stress from a negative working environment and counseling support through family discussion were also hypothesized.

\section{Results}

Table 1 shows that the mean total job stress among police officers was 2.92 , with a standard deviation of 0.981 . Respondent police officers were predominantly male $(86.7 \%)$. The mean age was 36.09 years old with a standard deviation of 8.113. Respondent officers were also predominantly white $(80.5 \%)$ with a small percentage belonging to a racial minority group (19.5 $\%$ ). Educational attainment of the respondents also varied: $31.6 \%$ have a bachelor's degree or higher, while $68.4 \%$ of respondents have less than a bachelor's degree. More than a majority of respondents held the rank of officer $(58.2 \%)$, while less than a majority (41.8\%) were 
supervisors. The mean of respondent officers' years of service was 12.20 , with a standard deviation of 7.430 years.

With respect to work environment variables, all three were latent variables with approximate middle level responses. The mean of a negative working environment was 2.74, with a standard deviation of 0.910 , indicating that respondent officers felt "a little" to "some" level of impact on them or their families. In addition, the mean of counseling support was 3.23, with a standard deviation of 0.886 , suggesting that respondent officers "neither agree nor disagree" to "moderately agree" that their work environment was supportive of counseling. Similarly, the mean level of family discussion with co-workers was 3.43 , with a standard deviation of 1.108 , showing that respondent officers "neither agree nor disagree" to "moderately agree" that they were able to discuss family and personal matters with co-workers.

Taking measures of absolute and incremental fits as well as parsimony into consideration, several models were modified and re-tested to fit the data (Hu \& Bentler, 1995). Figure 2 summarizes the empirical results of the structural equation model of total job stress among police officers. Only significant variables and significantly-related standardized coefficients are reported. The values of the covariance among variables are omitted. Compared to the hypothesized model in Figure 1, the results indicate that there was a significant difference between the hypothesized model and the empirical model. The following fit indices shows that the final model was a good fit. The value of CMIN/DF was 2.238, lower than 3 as generally indicated, illustrating a well fit in a large sample size (Dukes et al., 2009; Iwasaki, 2003; Ortega et al., 2007). Meanwhile, the value of GFI was 0.959, which indicates a strong fit, while the values of AGFI and CFI were 0.927 and 0.969 , respectively, suggesting a good fit (Hoyle \& 
Panter, 1995; Hu et al., 1992; Schumacker \& Lomax, 2004). Finally, the value of RMSEA was 0.046 below the cutoff of 0.05 , also indicating a good fit (Hu \& Bentler, 1999).

The results from the structural equation modeling show that sex did not have a direct impact on total job stress among police officers but was a significant predictor of family discussion with co-workers. Compared to females, male officers report lower levels of family discussion with co-workers (beta $=-.119$ ). In addition, race did not have a direct impact on police officers' total job stress, but it was also a significant predictor of family discussion with co-workers. Compared to racial minorities, white police officers report higher levels of family discussion with co-workers $($ beta $=.117)$.

In turn, educational achievement did not have a direct impact on police officers' total job stress, but it had a significant negative association with counseling support (beta $=-.091)$, indicating that the higher the educational attainment of police officers, the lower their perceptions of counseling support. Police officers who report lower levels of counseling support had significantly higher levels of total job stress (beta $=-.140)$. Meanwhile, position tenure did not have a direct impact on police officers' total job stress, but it had a significant positive effect on a negative working environment (beta $=.230$ ). The longer a police officer serves in a position, the more involvement and organizational influence ensued. Also, the higher the effect of a negative working environment, the more the police officers were influenced by total job stress $($ beta $=.739)$.

Rank was another important demographic variable. It was the only variable which had a direct impact on both total job stress and two endogenous variables (i.e., negative working environment and family discussion with co-workers). Police officers with a higher rank, such as supervisors report higher levels of total job stress (beta $=.140$ ). In addition, police officers with 
a higher rank (e.g., supervisors) report higher levels of family discussion with co-workers (beta $=$ .123) and lower impact of a negative working environment (i.e., danger associated with job, closed society of policing, organizational hierarchy, and officer and family are expected to behave) on them or their family (beta $=-.170$ ). However, the results show that there was no statistically significant association between family discussion with co-workers and total job stress.

The unstandardized coefficients of variables and the R-Square values of endogenous variables are presented in Table 2 . The final R-Square value indicates that the empirical model explains $63 \%$ of the variance of total job stress among police officers.

\section{Conclusion}

Over the past four decades, researchers have identified relevant factors that lead to police job stress. Previous studies report that demographic characteristics, the inherent dangers of police work, work environment and peer support, work-family conflict, and administratively organizational practices all contribute to police job stress (Burke, 1989; Hawkins, 2001; Morash et al., 2006; Morash \& Kwak, 2006; Violanti \& Aron, 1995; Zhao et al., 1999). Some studies show that police work environment and individual behavioral attributes play a more important role on job stress among police officers than personal characteristics (Zhao, He, Lovrich, \& Cancino, 2003). Heffren and Hausdorf (2016, p. 426), for example, reported that among 421 police officers in a large municipal police force in Canada, positive attitudes toward disclosing stress at work was significantly negatively related to respondents dealing with the trauma themselves $\left(\mathrm{B}=-1.79\right.$, Wald $\left.\chi^{2}=13.24, \mathrm{p}<.001\right)$, significantly positively related to 
respondents seeking help from a friend at work $(\mathrm{B}=2.06$, Wald $\chi 2=15.83, \mathrm{p}<.001)$ and outside of work $(B=1.52$, Wald $\chi 2=11.15, \mathrm{p}<.001)$.

This article examines the relationships between demographic characteristics, negative working environment, counseling support, and family discussion with co-workers and their impact on total job stress among a random sample of police officers in New York City. Using structural equation modeling, results of analysis indicate that sex, race, education, and years served in law enforcement only indirectly influence total job stress among police officers, but directly impact levels of family discussion with co-workers, counseling support, and negative working environment. This study shows also that rank directly impacts total stress, negative working environment, and family discussion with co-workers. Both negative working environment and counseling support directly impact police job stress. Although sex does not directly impact total job stress, female officers report higher levels of family discussion with coworkers.

Our study is consistent with research reporting the absence of gender differences in psychological stress experienced by police officers (Hassell, Archbold, \& Stichman, 2011) but that coping mechanisms (e.g., work life balance and stability at home) reduce physical symptoms of stress (Gachter, Savage, \& Torgler, 2011). There are contrary studies, however, indicating that female officers have higher levels of depression and somatization than their male counterparts because of the nature of the police profession (De Guzman, 2017; Zhao et al., 2003). Krimmel and Gormley (2003) also report a negative effect of gender on stress (being a female officer in the male-dominated work environment), concluding that women in police departments with less than $15 \%$ females have high levels of job-related depression and low self-esteem. 
Extant literature also indicates that White officers have higher emotional exhaustion and depersonalization scores (Hawkins, 2001). These provide a strong explanation of the results of the current article: White police officers have a more positive coping mechanisms through sharing and discussing family experiences with co-workers than their counterpart officers from other racial minority groups. Police officers with higher levels of education are less agreeable with the idea that their working environment was supportive of counseling. Likewise, previous research states that the longer a police officer serves in law enforcement, the greater the likelihood of emotional exhaustion (Hawkins, 2001). Particularly, officers with six to 10 years of service experience more stress than those with one to five years of service (Volanti \& Aron, 1995). The current article similarly reports that the longer a police officer serves in a position, the greater the impact of a negative working environment.

Contrary to previous research that report higher ranking officers were less stressed than lower ranking officers (Arter, 2007; Stotland et al., 1989) and that greater control in decisionmaking and more involvement diminishes job stress (Morash et al., 2006), the current article reports that police officers with higher ranks as supervisors experience higher levels of total job stress. The current findings are supported by Lord's (1996) study, finding that the more police participate in decision-making, the greater the stress they experience. Higher ranking officers are involved in more decision-making processes and therefore took on more responsibility, leading to higher strain. Similar to extant literature showing that lower ranking police officers experience greater levels of stressors from their working environment, the present article reveals that higher ranking police officers engage in more coping mechanisms through discussing personal experiences with co-workers and are less influenced by a negative working environment. One possible explanation for the results is that lower ranking police officers had 
more tedious and routine daily activities that expose them directly to their work environment, which increase their daily interactions with peers and first-line duties. Thus, they handle their work environment and manage organizational pressures, concomitantly increasing their job stress (Violanti \& Aron, 1995).

Prior studies indicate the need for future research to focus on the "perceived availability of, and incentives for using, human resources (e.g. counseling services, peer supports), workout facilities, and other stress-reducers" (McCarthy et al., 2011, p. 6). The current study analyzes the influence of work support for counseling services and peer support on police stress. Results of data analysis indicate on one hand that counseling support has a significantly negative direct impact on police job stress. However, family discussion with co-workers was not related to police total stress.

One limitation of this study is its focus only on one form of coping mechanism, namely, discussion of personal matters with work colleagues. Our study is consistent with other studies showing the lack of any significant direct association between discussing problems with coworkers and wellbeing factors (Ortega et al., 2007). Other forms of coping mechanisms, such as bonding with co-workers, physical and social activities with family and co-workers outside of the work environment, and quality of peer relationships may be more determinative of job satisfaction or job stress. Ortega et al. (2007) point out that coping strategies are directly associated with organizational commitment and job satisfaction. Previous literature suggest that social support networks such as family, work supervisors, friends, and colleagues help ameliorate stress. The current article also supports the idea that lack of social support can exacerbate the effects of job stress on physiological and psychological health (Cullen et al., 1985; LaRocco et al., 1980). Also, the unique nature of the job and its effect on relationships 
between police officers and their families need to be particularly addressed. The distinct characteristics of law enforcement work have crucial impact on police officers and their families, making it difficult for police officers to share work experience with family members and to balance work and family responsibilities (Burke, 1993; Jackson \& Maslach, 1982; Ortega et al., 2007). Rees and Smith (2008, p. 277) urge the necessity for police departments to provide more support services such as counseling, debriefing, and "force chaplains to assist the officers to talk through, and come to terms with, the traumatic experiences they have." Information on trauma and its repercussions at the earliest possible time enables police officers and employees to deal with trauma and cope with stress more effectively (Rees \& Smith, 2008).

Zhao et al. (1999) finds that the work environment explains more variation in job satisfaction than police officers' demographic attributes. Likewise, He et al. (2005) reports that work environment and coping mechanisms contribute more to explaining total police stress than race and gender. In terms of work environment, Ortega et al. (2007) concludes that occupational stressors are related to low organizational commitment and leads to poor overall job satisfaction. Herzberg's (2005) motivation-hygiene theory further distinguishes between hygiene factors that lead to job dissatisfaction and motivators that lead to job satisfaction. Herzberg (2005) argues that management should focus on hygiene factors to lessen or eliminate job dissatisfaction. On the other hand, focusing on motivators leads to job satisfaction among employees. The results of this article support prior literature showing that negative working environment is a major predictor of total police job stress. Our findings also reveal similar results indicating that negative working environment as a hygiene factor and positive working environment as a motivator both have strong influence on job stress. 
Stinchcomb (2004) contends that chronic organizational stress occurs on a daily basis and that police officers are constantly exposed to the pressures of organizational structures and policies. To counter organizational stress, he suggests that management should be more participatory, and implement such strategies as team-building, empowering employees, improving communication among leadership and employees, and changing stress-inducing organizational policies and practices. Research also shows that expressing emotions associated with the job appear to reduce stress. Scholars suggest that police officers may reduce job stress through writing or expressing emotions as well as encouraging them to avail themselves to various support services (Beehr et al., 1990; Cohen \& Wills, 1985; Ireland et al., 2006).

Another limitation of this article is that the dataset analyzed examines only one time period (1995) in several police departments in New York City and surrounding areas. Ortega et al. (2007) emphasize the importance of longitudinal studies to provide a more reliable understanding of the factors that influence job stress. Since individual traits and working environment are not fixed and change over time, future research should focus on longitudinal analysis of total job stress among police officers. Future research should also examine the presence and utility of more sex-specific or sex-appropriate forms of departmental or agency support that can target the needs of both male and female officers. Police departments should establish support programs that enable police officers to deal with job stress. Team-building activities that enable officers to maintain positive peer interactions as well as cultivate interactions across various ranks may reduce job stress. Finally, police departments should explore support programs that help married officers deal with the unique character of the stress associated with their jobs. 


\section{References}

Alexander, D., Innes, G., Irving, B., Sinclair, S., \& Walker, L. (1991). Police stress at work. London: The Police Foundation.

Arter, M. (2007). Stress and deviance in policing. Deviant Behavior, 29, 43-69.

Ayres, R., \& Flanagan, G. (1990). Preventing law enforcement stress: The organization's role. Washington, DC: Bureau of Justice Assistance, U.S. Department of Justice.

Backteman-Erlanson, S., Padyab, M., \& Brulin, C. (2013). Prevalence of burnout and associations with psychosocial work environment, physical strain, and stress of conscience among Swedish female and male police personnel. Police Practice \& Research, 14, 491-505.

Band, S., \& Manuelle, C. (1987). Stress and police officers' performance: An examination of effective coping behavior. Journal of Police and Criminal Psychology, 3(3), 30-42.

Beehr, T., King, L., \& King, D. (1990). Social support and occupational stress: Talking to supervisors. Journal of Vocational Behavior, 36, 61-81.

Belknap, J., \& Shelley, J. (1992). The new lone ranger: Police women on patrol. American Journal of Police, 12(2), 47-75.

Bentler, P.M. (2006). EQS 6 structural equations program manual. Encino, CA: Multivariate Software, Inc.

Biggam, F., Power, K., MacDonald, R., Carcary, W., \& Moodie, E. (1997). Self-perceived occupational stress and distress in a Scottish police force. Work and Stress, 11, 118-133.

Bolman, L., \& Deal, T. (2003). Reframing organizations. San Francisco: Jossey-Bass.

Brown, J., \& Campbell, E. (1994). Stress and policing: Sources and strategies. New York: John Wiley. 
Brown, J., Fielding, J., \& Grover, J. (1999). Distinguishing traumatic, vicarious, and routine operational stressor exposure and attendant adverse consequences in a sample of police officers. Work \& Stress, 13, 312-325.

Burke, R. (1989). Career stages, satisfaction, and well-being among police officers. Psychological Reports, 65, 3-12.

Burke, R. (1993). Organizational level interventions to reduce occupational stressors. Work \& Stress, 7, 77-87.

Buzawa, E. (1984). Determining patrol officer job satisfaction: The role of selected demographic and job-specific attitudes. Criminology, 22, 61-81.

Carmines, E., \& McIver, J. (1981). Analyzing models with unobserved variables: Analysis of covariance structures. In G. W. Bohrnstedt \& E. F. Borgatta (Eds.), Social measurement: Current issues (pp. 65-115). Beverly Hills, CA: Sage.

Carter, D., \& Sapp, A. (1990). The evolution of higher education in law enforcement: Preliminary findings from a national study. Journal of Criminal Justice Education, 1, 5985.

Chu, D. (2015). Police officer stress awareness and management: A handbook for practitioners. Police Practice \& Research, 16, 446-447.

Cohen, S., \& Wills, T. (1985). Stress, social support, and the buffering hypothesis. Psychological Bulletin, 98, 310-357.

Cooper, C., \& Davidson, M. (1987). Sources of stress at work and their relation to stressors in non-working environments. In R. Kalimo, M. El-Batawi, \& C. Cooper (Eds.), Psychological factors at work and their relation to health (pp. 99-123). Geneva: World Health Organization. 
Crank, J., \& Caldero, M. (1991). The production of occupational stress in medium sized-police agencies: A survey of line officers in eight municipal departments. Journal of Criminal Justice, 19, 339-349.

Crowe, G., \& Stradling, S. (1993). Dimensions of perceived stress in a British police force. Policing and Society, 3, 137-150.

Cullen, F., Lemming, T., Link, B., \& Wozniak, J. (1985). The impact of social supports on police stress. Criminology, 23, 503-522.

Dantzker, M. (1992). An issue for policing -- educational level and job satisfaction: A research note. American Journal of Police, 12(2), 101-118.

Dawson, D., \& Reid, K. (1997). Fatigue, alcohol, and performance impairment. Nature, 388, 235.

De Guzman, M. (2017). Gender issues in policing: Towards a more viable theory for interventions and research. In R. Burke (Ed.), Stress in policing: Sources, consequences and intervention (pp. 81-94). New York, NY: Routledge.

Delprino, R., O’Quin, K., \& Kennedy, C. (2000). Work and family services for law enforcement personnel in the United States, 1995. ICPSR version: Buffalo State College. Ann Arbor, MI: Inter-University Consortium for Political and Social Research.

Dick, P. (2000). The social construction of the meaning of acute stressors: A qualitative study of the personal accounts of police officers using stress counseling service. Work \& Stress, $14,226-244$.

Dowler, K., \& Arai, B. (2008). Stress, gender, and policing: The impact of perceived gender discrimination on symptoms of stress. International Journal of Police Science and Management, 10, 123-135. 
Dukes, R., Portillos, E., \& Miles, M. (2009). Models of satisfaction with police service. Policing: An International Journal of Police Strategies \& Management, 32, 297-318.

Ellrich, K. (2016). Burnout and violent victimization in police officers: A dual process model. Policing: An International Journal of Police Strategies \& Management, 39, 652-666.

Federal Bureau of Investigation (2011). Uniform Crime Reports, Full-time Law Enforcement Employees by State by City, 2011. Accessed on https://ucr.fbi.gov/crime-in-theu.s/2011/crime-in-the-u.s.-2011/police-employee/city-agency

Finn, P. (1997). Reducing stress: An organization-centered approach. FBI Law Enforcement Bulletin, 66(8), 20-26.

Finn, P. (1999). Reducing stress: An organization-centered approach. In L. Territo \& J. D. Sewell (Eds.), Stress management in law enforcement (pp. 373-382). Durham, NC: Carolina Academic Press.

Fletcher, B. (1988). The epidemiology of occupational stress. In C. Cooper \& R. Payne (Eds.), Causes, coping, and consequences of stress at work (pp. 12-57). Chichester, UK: Wiley.

Franke, R., \& Kaul, J. (1978). The Hawthorne experiments: First statistical interpretation. American Sociological Review, 43, 623-643.

Gachter, M., Savage, D., \& Torgler, B. (2011). Gender variations of physiological and psychological strain amongst police officers. Gender Issues, 28, 66-93.

Gibson, C., Zhao, J., Lovrich, N., \& Gaffney, M. (2002). Social integration, individual perceptions of collective efficacy, and fear of crime in three cities. Justice Quarterly, 19, $537-564$.

Graves, W. (1996). Police cynicism: Causes and cures. FBI Law Enforcement Bulletin, 65(6), 16-20. 
Greller, M., Parsons, C., \& Mitchell, D. (1992). Additive effects and beyond: Occupational stressors and social buffers in police organization. In J. D. Quick, L. R. Murphy, \& J. J. Hurrell, Jr. (Eds.), Stress and well-being at work: Assessments and interventions for occupational mental health (pp. 33-47). Washington, DC: American Psychological Association.

Gudjonsson, G., \& Adam, R. (1985). Occupational stressors among British police officers. Police Journal, 58(1), 73-80.

Hart, P., Wearing, A., \& Headley, B. (1994). Perceived quality of life, personality, and work experiences: Construct validation of the police daily hassles and uplifts scales. Criminal Justice and Behavior, 21, 283-311.

Hart, P., Wearing, A., \& Headley, B. (1995). Police stress and well-being: Integrating personality, coping, and daily work-experiences. Journal of Occupational and Organizational Psychology, 68, 133-156.

Hassell, K., Archbold, C., \& Stichman, A. (2011). Comparing the workplace experiences of male and female police officers: Examining workplace problems, stress, job satisfaction, and consideration of career change. International Journal of Police Science and Management, $13,37-53$.

Hawkins, H. (2001). Police officer burnout: A partial replication of Maslach's burnout inventory. Police Quarterly, 4, 343-360.

He, N., Zhao, J., \& Ren, L. (2005). Do race and gender matter in police stress? A preliminary assessment of the interactive effects. Journal of Criminal Justice, 33, 535-547.

Heffren, C., \& Hausdorf, P. (2016) Post-traumatic effects in policing: Perceptions, stigmas and help seeking behaviours. Police Practice \& Research, 17, 420-433. 
Herzberg, F. (2005). Motivation-hygiene theory. In J. B. Miner (Ed.), Organizational behavior I: Essential theories of motivation and leadership (pp. 61-74). New York: M.E. Sharpe.

Higgins, G., Ercikti, S., \& Vito, G. (2013). Job satisfaction: Validating Dantzker's four-factor model using structural equation modeling. Criminal Justice Studies, 26, 19-29.

Houdmont, J. (2017). Stressors in police work and their consequences. In R. Burke (Ed.), Stress in policing: Sources, consequences and intervention (pp. 51-65). New York, NY: Routledge.

Hoyle, R., \& Panter, A. (1995). Writing about structural equation models. In R. H. Hoyle (Ed.), Structural equation modeling: Concepts, issues, and applications (pp. 158-176). Thousand Oaks, CA: Sage Publications.

Hu, L., \& Bentler, P. (1995). Evaluation model fit. In R. H. Hoyle (Ed.), Structural equation modeling: Concepts, issues, and applications (pp. 76-99). Thousand Oaks, CA: Sage Publications.

Hu, L., \& Bentler, P. (1999). Cutoff criteria for fit indexes in covariance structure analysis: Conventional criteria versus new alternatives. Structural Equation Modeling: A Multidisciplinary Journal, 6, 1-55.

Hu, L., Bentler, P., \& Kano, Y. (1992). Can test statistics in covariance structure analysis be trusted? Psychological Bulletin, 112, 351-362.

Hunt, R., \& McCadden, K. (1985). A survey of work attitudes of police officers: Commitment and satisfaction. Police Studies, 8(1), 17-25.

Ireland, M., Malouff, J., \& Byrne, B. (2006). The efficacy of written emotional expression in the reduction of psychological distress in police officers. International Journal of Police Science \& Management, 9, 303-311. 
Iwasaki, Y. (2003). Examining rival models of leisure coping mechanisms. Leisure Sciences, 25, 183-206.

Jackson, S., \& Maslach, C. (1982). After effects of job related stress: Families as victims. Journal of Occupational Behavior, 3, 63-77.

Jespersen, A. (1988, February). New approaches to stress. Police Review, 436-437.

Jöreskog, K., \& Sörbom, D. (1989). LISEREL7-A guide to the program and applications. Chicago: SPSS.

Kanter, R. (1977). Men and women of the corporation. New York: Basic Books.

Kirkcaldy, B., Cooper, C., \& Ruffalo, P. (1995). Work stress and health in a sample of U.S. police. Psychological Reports, 76, 700-702.

Kirschman, E. (1998). Organizational stress. Police Chief, 65(10), 127-134.

Kline, R. (2005). Principles and practice of structural equation modeling ( $2^{\text {nd }}$ ed.). New York: Guilford Press.

Kop, N., Euwema, M., \& Schaufeli, W. (1999). Burnout, job stress, and violent behavior among Dutch police officers. Work and Stress, 13, 326-340.

Korre, M., Farioli, A., Varvarigou, V., Sato, S., \& Kales, S. (2014). A survey of stress levels and time spent across law enforcement duties: Police chief and officer agreement. Policing, 8, $109-122$.

Krimmel, J., \& Gormley, P. (2003). Tokenism and job satisfaction for policewomen. American Journal of Criminal Justice, 28, 73-88.

Kula, S. (2017). Occupational stress, supervisor support, job satisfaction, and work-related burnout: Perceptions of Turkish National Police (TNP) members. Police Practice \& Research, 18, 146-159. 
Kula, S., \& Sahin, I. (2015). The impacts of occupational stress on the work-related burnout levels of Turkish National Police members. International Journal of Public Policy, 11(4/5/6), 169-185. DOI: http://dx.doi.org/10.1504/IJPP.2015.070565.

Kurtz, D. (2012). Roll call and the second shift: The influences of gender and family on police stress. Police Practice \& Research, 13, 71-86.

LaRocco, J., House, J., \& French, J. (1980). Social support, occupational stress, and health. Journal of Health and Social Behavior, 21, 202-218.

Lefkowitz, J. (1974). Job attitudes of police: Overall description and demographic correlates. Journal of Vocational Behavior, 5, 221-230.

Leitner, L., Posner, I., \& Lester, D. (1983). Stress, mood and job satisfaction in police chiefs. Police Chief, 50(1), 54-55.

Lester, D., Benkovich, J., Dietrich, M., \& Solis, A. (1981). Stress and job satisfaction in police officers. Police Studies, 4(1), 34-35.

Lord, V. (1996). An impact of community policing: Reported stressors, social support, and strain among police officers in a changing police department. Journal of Criminal Justice, 24, 503-522.

Love, K., \& Singer, M. (1988). Self-efficacy, psychological well-being, job satisfaction, and jobinvolvement: A comparison of male and female police officers. Police Studies, 11(2), 98102.

Malloy, T., \& Mays, L. (1984). The police stress hypothesis: A critical evaluation. Criminal Justice and Behavior, 11, 197-224.

Maslach, C. (1976). Burned-out. Human Behavior, 5(9), 16-22. 
Maslach, C., \& Jackson, S. (1981). The measurement of experienced burnout. Journal of Occupational Behavior, 2, 99-113.

McCarty, W. P., \& Lawrence, D. S. (2016). Coping, confidence, and change within the academy: A longitudinal look at police recruits. Police Practice \& Research, 17, 263-278.

McCarthy, W., Schuck, A., Skogan, W., \& Rosenbaum, D. (2011). Stress, burnout, and health. NCJRS235597. Retrieved from http://static1.1.sqspcdn.com/static/f/733761/10444483/1296183365827/Stress+Burnout+ +and+Health+FINAL.pdf?token=7CDAQIw5m8etjSIiyNcrt6uygEg\%3D

Morash, M., Haarr, R., \& Kwak, D. (2006). Multilevel influences on police stress. Journal of Contemporary Criminal Justice, 22, 26-43.

Morash, M., \& Kwak, D. (2006). Gender differences in the predictors of police stress. Policing: An International Journal of Police Strategies \& Management, 29, 541-563.

Oliver, W., \& Meier, C. (2004). Stress in small town and rural law enforcement: Testing the assumptions. American Journal of Criminal Justice, 29, 37-56.

Ortega, A., Brenner, S., \& Leather, P. (2007). Occupational stress, coping, and personality in the police: An SEM study. International Journal of Police Science and Management, 9, 3650.

Ott, J., Parkes, S., \& Simpson, R. (Eds.). (2008). Classic readings in organizational behavior. Belmont, CA: Thomson Wadsworth.

Pagon, M., Spector, P., Cooper, C., \& Lobnikar, B. (2011). Managers in suits and managers in uniforms: Sources and outcomes of occupational stress. International Journal of Police Science \& Management, 13, 211-222. 
Reiser, M., \& Geiger, S. (1984). Police officer as victim. Professional Psychology: Research and Practice, 15, 315-323.

Rees, B., \& Smith, J. (2008). Breaking the silence: The traumatic circle of policing. International Journal of Police Science \& Management, 10, 267-279.

Schuck, A., \& Rosenbaum, D. (2005). Global and neighborhood attitudes toward the police: Differentiation by race, ethnicity, and type of contact. Journal of Quantitative Criminology, 21, 391-418.

Schumacker, R., \& Lomax, R. (2004). A beginner's guide to structural equation modeling ( $2^{\text {nd }}$ ed.). New York: Psychology Press.

Sewell, J. (1999). Administrative concerns in law enforcement stress management. In L. Territo \& J. D. Sewell (Eds.), Stress management in law enforcement (pp. 361-371). Durham, NC: Carolina Academic Press.

Sherman, L. (1980). Causes of police behavior: The current state of quantitative research. Journal of Research in Crime and Delinquency, 17, 69-100.

Sigler, R., \& Wilson, C. (1988). Stress in the workplace: Comparing police stress with teacher stress. Journal of Police Science \& Administration, 16(3), 151-162.

Sigler, R., Wilson, C., \& Allen, Z. (1991). Police and teacher stress at work and at home. Journal of Criminal Justice, 19, 361-370.

Silbert, M. (1982). Job stress and burnout of new police officers. Police Chief, 49(6), 46-48.

Slate, R., Johnson, W., \& Colbert, S. (2007). Police stress: A structural model. Journal of Police and Criminal Psychology, 22, 102-112.

Spielberger, C., Westberry, L., Grier, K., \& Greenfield, G. (1981). The police stress survey: Sources of stress in law enforcement. Tampa, FL: Human Resources Institute. 
Standfest, S. (1996). The police supervisor and stress. FBI Law Enforcement Bulletin, 65(5), 710.

Stevenson, T. (1988). Stress among police officers: Burnout and its correlates. Los Angeles California School of Professional Psychology. DAI-B 49/11, Dissertation Abstracts International.

Stinchcomb, J. (1995). Managing stress: Performing under pressure (Vol. 2). Lanham, MD: American Correctional Association.

Stinchcomb, J. (2004). Searching for stress in all the wrong places: Combating chronic organizational stressors in policing. Police Practice \& Research, 5, 259-277.

Storch, E., \& Panzarella, R. (1996). Police stress: State-trait anxiety in relation to occupational and personal stressor. Journal of Criminal Justice, 24, 99-107.

Stotland, E., Pendleton, M., \& Swartz, R. (1989). Police stress, time on the job, and strain. Journal of Criminal Justice, 17, 55-60.

Territo, L., \& Sewell, J. (1999). Stress management in law enforcement. Durham, NC: Carolina Academic Press.

Tyagi, A., \& Dhar, R. (2014). Factors affecting health of the police officials: Mediating role of job stress. Policing: An International Journal of Police Strategies \& Management, 37, 649-664.

Veniga, R., \& Spradley, J. (1981). The work/stress connection. Boston: Little, Brown.

Vila, B., Morrison, G., \& Kenney, D. (2002). Improving shift schedule and work-hour policies and practices to increase police officer performance, health, and safety. Police Quarterly, 5, 4-24. 
Violanti, J. (1996). Violence turned inward: Police suicide in the workplace. In G. R. Vandenbos \& E. Q. Bulatao (Eds.), Violence on the job: Identifying risks and developing solutions (pp. 229-249). Washington, DC: American Psychological Association.

Violanti, J., \& Aron, F. (1995). Police stressors: Variations in perceptions among police personnel. Journal of Criminal Justice, 23, 287-294.

Walker, M. (1997). Conceptual and methodological issues in the investigation of occupational stress: A case study of police officers deployed on body recovery at the site of the Lockerbie air crash. Policing and Society, 7, 1-17.

Williamson, A., \& Feyer, A. (2000). Moderate sleep deprivation produces impairments in cognitive and motor performance equivalent to legally prescribed levels of alcohol intoxication. Occupational and Environmental Medicine, 57, 649-655.

Wright, K., \& Saylor, W. (1991). Male and female employees' perceptions of prison work: Is there a difference? Justice Quarterly, 8, 508-524.

Yun, I., Hwang, E., \& Lynch, J. (2015). Police stressors, job satisfaction, burnout, and turnover intention among South Korean police officers. Asian Journal of Criminology, 10, 23-41.

Zhao, S., He, N., Lovrich, N., \& Cancino, J. (2003). Marital status and police occupational stress. Journal of Crime \& Justice, 26(2), 23-46.

Zhao, J., Thurman, Q., \& He, N. (1999). Sources of job satisfaction among police officers: A test of demographic and work environment models. Justice Quarterly, 16, 153-173. 
APPENDIX A. Confirmatory Factor Analysis Summary

\begin{tabular}{llccc}
\hline & \multicolumn{1}{c}{ Variables } & Estimate & S.E. & C.R. \\
\hline Total Job Stress & Overall stress & 1.000 & & \\
& Job stress & 1.826 & .113 & $16.106^{* * *}$ \\
& Burnout & 2.066 & .155 & $13.324 * * *$ \\
Negative Working & Danger & 1.000 & & \\
& Closed society & .941 & .081 & $11.594^{* * *}$ \\
& Hierarchy & .994 & .114 & $8.711^{* * *}$ \\
& Expect to behave & .738 & .093 & $7.947 * * *$ \\
Counseling Support & Supervisor support & 1.000 & & \\
& Top management support & 1.101 & .111 & $9.911 * * *$ \\
& Fellow officer support & .602 & .073 & $8.273 * * *$ \\
Family Discussion & Union support & .566 & .051 & $11.089^{* * *}$ \\
with Co-Workers & Discuss family members & 1.000 & & \\
\hline
\end{tabular}

Note: $* * *$ significant at $\alpha \leq .001$. 
TABLE 1. Descriptive Statistics ( $N=594$ )

\begin{tabular}{lllll}
\hline Variables & Measure & Mean & SD & Frequency (\%) \\
\hline $\begin{array}{l}\text { Dependent Variable } \\
\text { Total Job Stress }\end{array}$ & Ordinal (1-5) & 2.92 & 0.981 & \\
\hline $\begin{array}{l}\text { Independent Variables } \\
\text { Demographic Model }\end{array}$ & & & & \\
Sex & Male & & & $515(86.7)$ \\
& Female & & & $79(13.3)$ \\
Age & Continuous (22-62) & 36.09 & 8.113 & \\
Race & White & & & $478(80.5)$ \\
& Minority & & & $116(19.5)$ \\
Education & Bachelor \& Higher & & & $188(31.6)$ \\
& Less than Bachelor & & & $2406(68.4)$ \\
Rank & Supervisor & & & $346(58.2)$ \\
Tenure & Officer & & & \\
Work Environment & Continuous (0-30) & 12.20 & 7.403 & \\
Negative Working & Ordinal (1-5) & 2.74 & 0.910 & \\
Counseling Support & Ordinal (1-5) & 3.23 & 0.886 & \\
Family Discussion with & Ordinal (1-5) & 3.43 & 1.108 & \\
Co-Workers & & & & \\
\hline
\end{tabular}


TABLE 2. SEM Estimates on Negative Working, Family Discussion with Co-Workers, Counseling Support, and Stress Total $(\mathbf{N}=\mathbf{5 9 4})$

\begin{tabular}{|c|c|c|c|c|}
\hline Regression weights & (Unstandardized) & Estimate & S.E. & C.R. \\
\hline \multirow[t]{6}{*}{ Negative Working } & Sex & -.083 & 116 & -.715 \\
\hline & Age & -.020 & .011 & -1.775 \\
\hline & Race & -.029 & .100 & -.285 \\
\hline & Education & .072 & .083 & .875 \\
\hline & Rank & -.281 & .091 & $-3.101 * *$ \\
\hline & Tenure & .025 & .013 & $2.008 *$ \\
\hline \multirow[t]{6}{*}{ Counseling Support } & Sex & 249 & .131 & 1.906 \\
\hline & Age & .010 & .012 & .787 \\
\hline & Race & -.012 & .113 & -.106 \\
\hline & Education & -.187 & .094 & $-2.001 *$ \\
\hline & Rank & .195 & .101 & 1.928 \\
\hline & Tenure & -.005 & .014 & -.389 \\
\hline \multirow{8}{*}{$\begin{array}{l}\text { Family Discussion } \\
\text { with Co-Workers }\end{array}$} & Sex & -.317 & .116 & $-2.726 * *$ \\
\hline & Age & -.020 & .010 & -1.885 \\
\hline & Race & .267 & .100 & $2.668^{* *}$ \\
\hline & Education & -.044 & .075 & -.581 \\
\hline & Rank & .225 & .090 & $2.514^{*}$ \\
\hline & Tenure & -.001 & .011 & -.111 \\
\hline & Negative Working & .009 & .052 & .176 \\
\hline & Counseling Support & .016 & .043 & .374 \\
\hline \multirow[t]{9}{*}{ Total Job Stress } & Sex & -.070 & .059 & -1.200 \\
\hline & Age & .003 & .006 & .588 \\
\hline & Race & .086 & .051 & 1.686 \\
\hline & Education & .046 & .042 & 1.106 \\
\hline & Rank & .154 & .047 & $3.261 * *$ \\
\hline & Tenure & .000 & .006 & -.078 \\
\hline & Negative Working & .494 & .055 & $9.032 * * *$ \\
\hline & $\begin{array}{l}\text { Family Discussion with } \\
\text { Co-Workers }\end{array}$ & -.007 & .020 & -.345 \\
\hline & Counseling Support & -.082 & .026 & $-3.200 * *$ \\
\hline
\end{tabular}

Squared Multiple Correlations ( $R$-Square)

Negative $\quad$ Counseling Support Family Discussion with Co- $\quad$ Total Job Stress Working Workers

$\begin{array}{lll}.033 & .033 & .050\end{array}$

Note: $*$ significant at $\alpha \leq .05, * *$ significant at $\alpha \leq .01, * * *$ significant at $\alpha \leq .001$. 
FIGURE 1. Hypothesized Model of Path Analysis

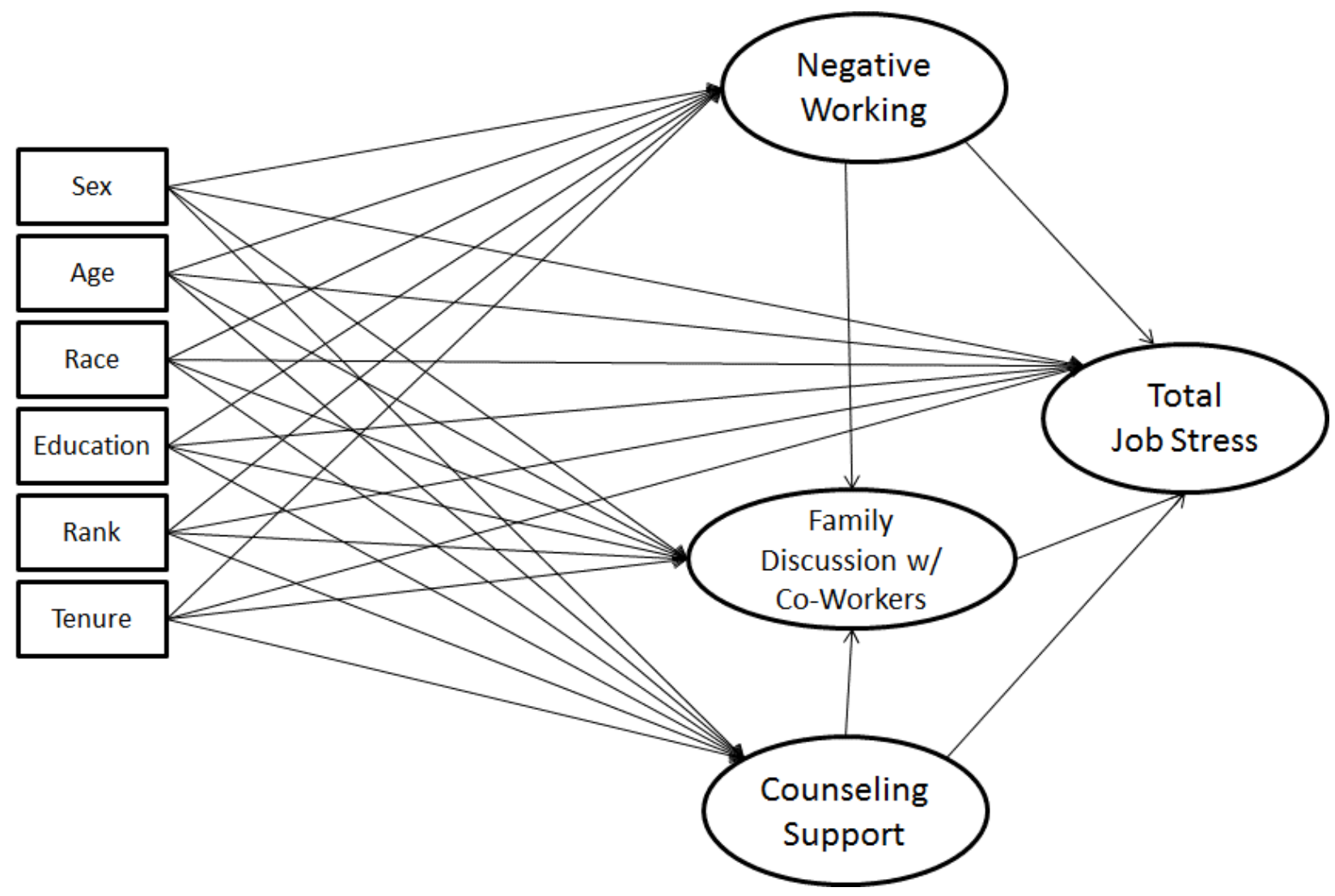


FIGURE 2. Empirical Model of Job Stress Total $(N=594)$

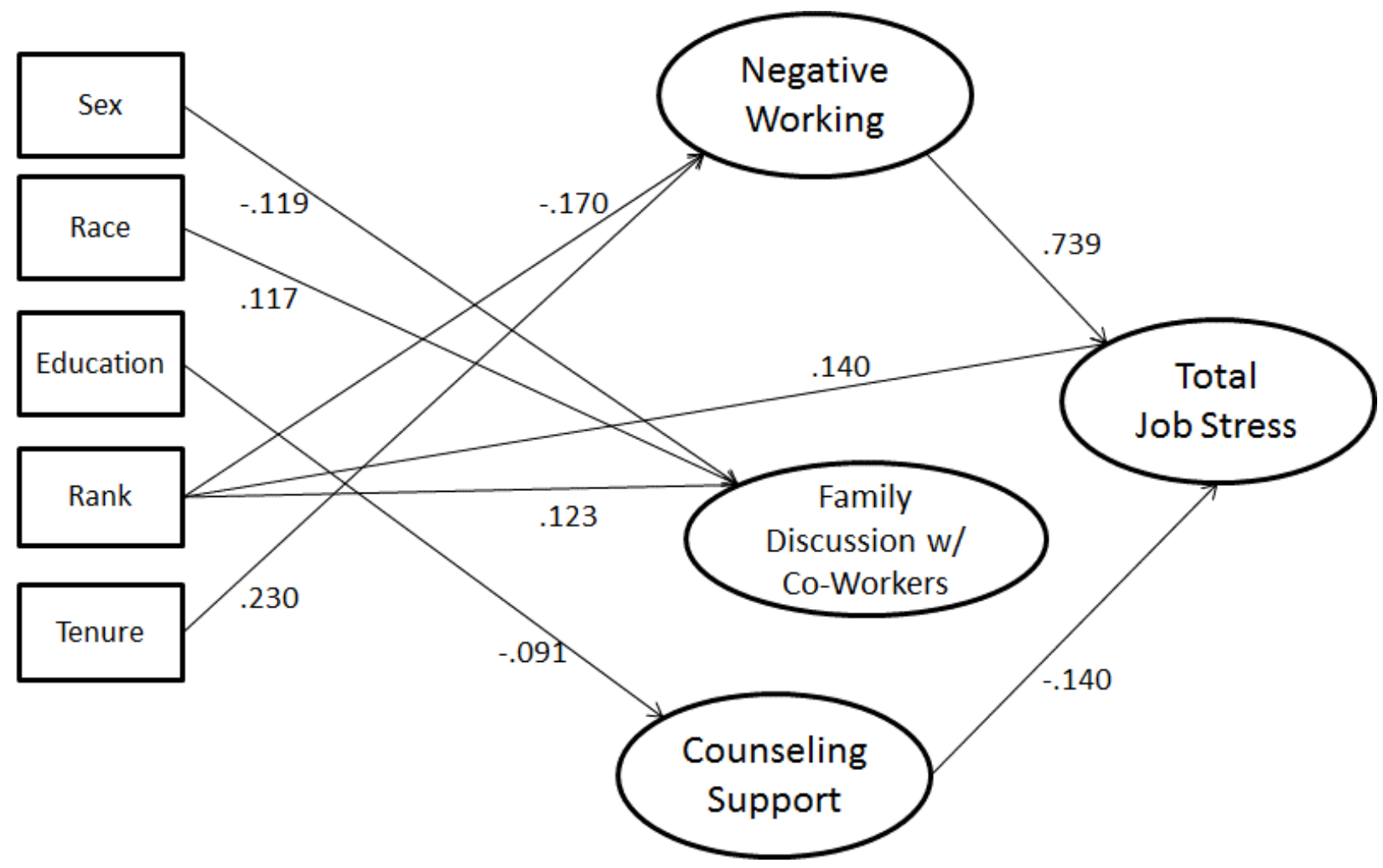

Note:

1. $\chi^{2}=237.264, d f=106, \rho<.001, \mathrm{CFI}=.969, \mathrm{GFI}=.959, \mathrm{AGFI}=.927, \mathrm{RMSEA}=.046$, $\chi^{2} / d f$ ratio $=2.238$

2. Only significant variables with standardized coefficients are presented. 